Article

\title{
Disinfection of Therapeutic Spa Waters: Applicability of Sodium Hypochlorite and Hydrogen Peroxide-Based Disinfectants
}

\author{
Dóra Gere $^{1,2}$ (D) Eszter Róka ${ }^{2}$, Gyula Záray ${ }^{1,3}$ and Márta Vargha ${ }^{2, *(\mathbb{D})}$ \\ 1 Hevesy György PhD School of Chemistry, Eötvös Loránd University, Pázmány Péter Street 2., \\ 1117 Budapest, Hungary; gere.dora@nnk.gov.hu (D.G.); zaray.gyula@ecolres.hu (G.Z.) \\ 2 Environmental Hygiene Department, National Public Health Center, Albert Flórián Street 2-6., \\ 1097 Budapest, Hungary; roka.eszter@nnk.gov.hu \\ 3 Department of Danube's Diversity, Institute of Aquatic Ecology, Centre for Ecological Research, \\ Karolina Street 29, 1113 Budapest, Hungary \\ * Correspondence: vargha.marta@nnk.gov.hu
}

check for updates

Citation: Gere, D.; Róka, E.; Záray, G.; Vargha, M. Disinfection of Therapeutic Spa Waters: Applicability of Sodium Hypochlorite and Hydrogen Peroxide-Based Disinfectants. Water 2022, 14, 690. https://doi.org/ $10.3390 / \mathrm{w} 14050690$

Academic Editor: Hong Chen

Received: 5 January 2022

Accepted: 18 February 2022

Published: 22 February 2022

Publisher's Note: MDPI stays neutral with regard to jurisdictional claims in published maps and institutional affiliations.

Copyright: (C) 2022 by the authors. Licensee MDPI, Basel, Switzerland. This article is an open access article distributed under the terms and conditions of the Creative Commons Attribution (CC BY) license (https:// creativecommons.org/licenses/by/ $4.0 /)$.

\begin{abstract}
The microbial water quality of therapeutic pools operating without disinfection is recurrently compromised, posing a risk to bathers' health. The complex composition of such waters and the sensitivity of their therapeutic components hinder the use of traditional chlorine-based disinfectants. The present study aimed to investigate the applicability of a hydrogen peroxide-based disinfectant in therapeutic water in comparison with hypochlorite. Disinfection efficacy, byproduct formation, and the fate of therapeutic components were tested for both disinfectants under laboratory conditions, applying different doses and contact times. Disinfection efficacy was found to be matrix-dependent, especially that of hydrogen peroxide against Pseudomonas aeruginosa (a 10- to 1000-fold difference). Hypochlorite treatment presented a significant chemical risk through the generation of byproducts, mainly brominated and iodinated compounds and combined chlorine. Of the alleged therapeutic components, sulfide ions were eliminated ( $\geq 86 \%$ loss) by both disinfectants, and hypochlorite reacted with iodide ions as well ( $\geq 70 \%$ removal). Based on their composition, only $2 \%$ of Hungarian therapeutic waters can be treated by chlorination due to high concentrations of ammonia and/or organic compounds. Hydrogen peroxide is applicable to $82 \%$ of the waters, as the presence of sulfide ions is the only limiting factor. Due to the matrix effect, close control of residual disinfectant concentration is necessary to ensure microbial safety.
\end{abstract}

Keywords: water quality; disinfection; balneology; baths; swimming pools; mineral waters; hydrogen peroxide; sodium hypochlorite; Pseudomonas aeruginosa; Escherichia coli

\section{Introduction}

Balneotherapy is a long-standing tradition in Europe. It is a recognized complementary therapy in the treatment of musculoskeletal, dermatological, and gynecological problems, among others [1,2]. At the same time, bathing in spas can pose a risk to health if the water is microbiologically unsafe, especially for the elderly and immunocompromised people who are the primary target audience of balneotherapy [3-6].

Traditionally, pool water quality in therapeutic pools is ensured by dilution-based methods (large-scale water replenishment, frequent water exchange) and user behavior (limited pool load and improved bather hygiene). While these measures are important, they are often insufficient against microbial contamination. Several pool water-related diseases can be associated with untreated therapeutic waters $[4,7,8]$. In Hungary, according to monitoring data from the public health authorities, microbial water quality is significantly more frequently non-compliant in therapeutic fill-and-drain pools than in other types of bathing facilities, e.g., in swimming pools $[9,10]$. 
An ideal disinfectant for the treatment of therapeutic pools would eliminate pathogens while leaving the healing effects of the water unchanged. Hungarian regulations link the certification of therapeutic waters, and thus implicitly their therapeutic effect, to the presence of certain chemical components. The components designated in the Ministerial Decree on natural healing factors are: total mineral content; iodide, bromide, sulfide, and lithium ions; metasilicic acid; free carbon dioxide; and radon gas [11].

Their complex composition, frequently high organic and mineral content, and generally high temperature are further challenges in the chemical disinfection of therapeutic waters. Several alternative methods have been suggested for disinfecting thermal and therapeutic waters, while others may be considered based on experiences in other fields; these include ultraviolet (UV) light treatment [4,12], ultrafiltration [13], and the use of nanomaterials [14,15]. Advanced oxidation processes (AOP) based on different methods such as the combination of $\mathrm{UV} / \mathrm{H}_{2} \mathrm{O}_{2} / \mathrm{O}_{3}$, nanomaterials, or electrocoagulation are becoming widespread [16-18]. However, alternative methods often entail high costs, and the fouling of UV lamps can be significant in waters with a high mineral content. Physical methods only act at the point of application, and do not provide protection against bather-derived contamination in the pool. Due to the high oxidative power and complex chemistry of AOP processes, the overall composition of therapeutic water may change significantly over time. For the components considered to be therapeutic, UV and ultrafiltration methods have been shown not to alter the sulfide ion or metasilicic acid content of the treated water $[4,13]$.

Most common chemicals used in swimming pool water disinfection contain chlorinebased active ingredients such as chlorine gas or sodium hypochlorite. Their main advantages are good disinfection efficacy, easy handling, and low cost. Although their disinfection efficiency has been demonstrated in tap water, it may be different in therapeutic waters with different compositions. The formation of byproducts which are often harmful to health is a serious limitation on the use of chlorine-based disinfectants in waters with high organic matter content [19-21].

Alternatively, disinfectants containing hydrogen peroxide may be applied [22-24]. Hydrogen peroxide-based disinfectant products usually contain a stabilizer and/or other biologically active ingredients to enhance disinfection efficacy, e.g., silver or quaternary ammonium polymers. Due to their slower mechanism of action and higher price range, they are less common in swimming pool water treatment and are typically used in lower-load home pools or children's pools [6,25]. Their advantage in therapeutic water disinfection may be the absence of byproduct formation, although evidence is limited in this area. Recently, a hydrogen peroxide-based disinfectant containing a quaternary ammonium polymer, N-methyl-methanamine-(chloromethyl)oxirane, has been introduced in several Hungarian spas.

Both active chlorine and hydrogen peroxide have oxidizing properties, and can therefore react with the presumptive therapeutic components of these waters. Their reactions with sulfide [26-30], bromide [31-33], and iodide ions [34-37] have been described in the literature; however, reaction conditions are not always similar to those in therapeutic waters.

The aim of our series of experiments was to compare chlorine-based and hydrogen peroxide-based disinfectants. Certified therapeutic water was treated in laboratory model experiments with two commercially available pool water disinfectants. The efficacy of the disinfectants and their effects on chemical composition and byproduct formation were investigated to obtain a complex picture of their respective advantages and disadvantages.

The available literature on the disinfection options of therapeutic waters is scarce. To ensure microbial safety of the pools as well as to identify suitable means of cleaning is indispensable. The present study is the first attempt to investigate the applicability of a hydrogen peroxide-based disinfectant. The results shed light on the challenges of hypochlorite treatment of therapeutic waters, including byproduct formation and the fate of therapeutic components. As compositional data on Hungarian therapeutic waters was at our disposal, the treatability of domestic waters became quantifiable as well, presenting an important data source for domestic spa operators and stakeholders. 


\section{Materials and Methods}

Test water

Water from a certified therapeutic well in Budapest was used for the disinfection experiments. The water was of a mixed nature, with the main ions $\mathrm{Na}^{+}, \mathrm{Ca}^{2+}, \mathrm{Mg}^{2+}, \mathrm{Cl}^{-}$, $\mathrm{SO}_{4}{ }^{2-}$, and $\mathrm{HCO}_{3}{ }^{-}$. While its certification was based on total mineral content, it contained sulfide-, bromide-, iodide-ions, and metasilicic acid. A detailed description of the water is presented in the Results and Discussion section. Test water was collected directly from the well and transported to the laboratory, where it was processed immediately or stored at $4{ }^{\circ} \mathrm{C}$ until use.

Disinfectants

Commercially-available formulated pool disinfectants were used for the disinfection experiments. Both products are approved biocides. Active ingredients were (1) hydrogen peroxide (47.9\%) and N-methyl-methanamine-(chloromethyl)oxirane $(2.4 \%)$ and (2) sodium hypochlorite (12-15\%); hereinafter, these are referred to as hydrogen peroxide and hypochlorite.

The applied doses were selected based on the values used in pools in practice [38]. Nominal concentrations for sodium hypochlorite (measured as free active chlorine) were (1) below breakpoint, (2) 0.5 , and (3) $1 \mathrm{mg} / \mathrm{L}$ free active chlorine residuals. In the case of hydrogen peroxide, concentrations of 30,100, $200 \mathrm{mg} / \mathrm{L}$ were used. The required reagent doses were determined by preliminary demand tests. In the case of sodium hypochlorite, the time required for the reaction to be completed was determined in advance. The respective hydrogen peroxide and free chlorine concentrations of the disinfectants were determined before each experiment. All treatments were replicated at least three times. After the desired contact time, disinfectant residues were neutralized using sodium thiosulfate.

Disinfection efficacy test

Test water samples were sterilized by membrane filtration on mixed ester filters with a $0.45 \mu \mathrm{m}$ pore size. The matrix effect control was tap water sterilized and dechlorinated by autoclaving. The test microorganisms were Escherichia coli, HNCMB 35033 (hereinafter: E. coli) and Pseudomonas aeruginosa, HNCMB 170554. Prior to inoculation with the test organisms, the level of disinfectant was adjusted to the desired level. The time required for the reaction of hypochlorite with chemical components to be completed was $10 \mathrm{~min}$ in most cases. Sterile tap water was inoculated as a control with and without disinfectant. During the test, samples were continuously stirred at ambient temperature. The contact time was $5 \mathrm{~min}$ for sodium hypochlorite and $30 \mathrm{~min}$ for hydrogen peroxide, due to the latter's slower disinfection mechanism. At the end of the reaction time, residual disinfectants were measured and the reaction was stopped by the addition of excess sodium thiosulfate. Aliquots of the sample (test samples: 1-300 mL, non-disinfected control sample: $0.1 \mathrm{~mL}$ ) were concentrated by membrane filtration and bacterial counts were determined by standard culture methods (ISO 9308-1:2000 for E.coli and ISO 16266:2006 for Pseudomonas aeruginosa, Table 1.

Investigation of the effect of disinfectants on the chemical composition

Aliquots of the test therapeutic well water were treated in the laboratory with the selected disinfectants in a closed bottle at room temperature. In the case of sulfide ions, due to the volatility of the component the disinfectants were added on site (at the therapeutic water well) and the closed bottles were delivered to the laboratory.

After the addition of the disinfectant, the samples were homogenized. The contact time was $1 \mathrm{~h}$ (simulating the disinfectant addition step of the water treatment) and $12 \mathrm{~h}$ (simulating the residence time of the water in the fill and drain systems). Untreated control samples were handled in the same manner, except for disinfectant dosing. The concentrations of the disinfectants were measured at the beginning and at the end of the contact time.

Measured parameters were electrical conductivity (inoLab Cond Level 2, WTW, Welheim, Germany), pH (pH330i/SET, WTW, Welheim, Germany), alkalinity, hardness, thera- 
peutic components (total mineral content, lithium, iodide, bromide, sulfide, metasilicate ions, silicon) and certain potential oxidation products (sulfate, iodate, bromate ions). Anions were measured by ion chromatography (Dionex ICS-5000+, Thermo Scientific, Waltham, MA, USA) except for sulfide and metasilicate ions which were measured with a UV-1800 UV-VIS spectrophotometer (Shimadzu, Kyoto, Japan). Lithium and silica were measured by ICP-MS (iCAP RQ ICP-MS, Thermo Scientific, Waltham, MA, USA). All chemicals used were purchased from Merck (Merck Group, Darmstadt, Germany).

Table 1. Analytical methods and standards used for characterization of water samples.

\begin{tabular}{|c|c|c|c|}
\hline Compound & Analytical Method & Standard & Detection Limit \\
\hline Hydrogen peroxide & $\begin{array}{l}\text { Titration in acidic media } \\
\text { with } \mathrm{KMnO}_{4}\end{array}$ & EPA guidance [39] & $0.1 \mathrm{mg} / \mathrm{L}$ \\
\hline $\begin{array}{l}\text { Total, free and bound } \\
\text { active chlorine }\end{array}$ & Titrimetric method & ISO 7393-1:2000 & $0.05 \mathrm{mg} / \mathrm{L}$ \\
\hline Escherichia coli & $\begin{array}{l}\text { Membrane filtration } \\
\text { method }\end{array}$ & ISO 9308-1:2000 & - \\
\hline Pseudomonas aeruginosa & $\begin{array}{l}\text { Membrane filtration } \\
\text { method }\end{array}$ & ISO 16266:2006 & - \\
\hline $\mathrm{pH}$ & Potentiometry & Hungarian standard 1484-22:2009 & - \\
\hline Electrical conductivity & Conductometry & ISO $7888: 1985$ & - \\
\hline $\begin{array}{l}\text { Alkalinity (hydrogen carbonate, carbonate, } \\
\text { hydroxyl ions) }\end{array}$ & Acid-base titration & $\begin{array}{l}\text { ISO 9963-1:1994 } \\
\text { ISO 9963-2:1998 }\end{array}$ & $0.1 \mathrm{mmol} / \mathrm{L}$ \\
\hline Hardness & Complexometry & Hungarian Standard 448-21:1986 & $1.0 \mathrm{mg} / \mathrm{L} \mathrm{CaO}$ \\
\hline Evaporation residue at $180{ }^{\circ} \mathrm{C}$ & Weighing & Hungarian Standard 448-19:1986 & $23 \mathrm{mg} / \mathrm{L}$ \\
\hline $\mathrm{Br}^{-}$ & \multirow{6}{*}{ Ion chromatography } & ISO 10304-1:2009 & $0.05 \mathrm{mg} / \mathrm{L}$ \\
\hline $\mathrm{I}^{-}$ & & ISO 10304-3:1999 & $0.03 \mathrm{mg} / \mathrm{L}$ \\
\hline \multirow{4}{*}{ Anions } & & ISO 10304-1:2009 & $5 \mathrm{mg} / \mathrm{L}$ \\
\hline & & ISO 10304-1:2009 & $2 \mathrm{mg} / \mathrm{L}$ \\
\hline & & ISO 15061: 2002 & $0.03 \mathrm{mg} / \mathrm{L}$ \\
\hline & & ISO 10304-4:2000 & $0.05 \mathrm{mg} / \mathrm{L}$ \\
\hline Sulfide ion & Spectrophotometry & Hungarian Standard 448-14:1990 ${ }^{1}$ & $0.1 \mathrm{mg} / \mathrm{L}$ \\
\hline Metasilicic acid & $\begin{array}{l}\text { Spectrophotometry } \\
\text { As silicon by ICP-MS }\end{array}$ & $\begin{array}{l}\text { Hungarian standard } 448-26: 1991^{2} \\
\text { ISO } 17294-2: 2017\end{array}$ & \multirow[t]{2}{*}{$2.0 \mathrm{mg} / \mathrm{L}$} \\
\hline Lithium & ICP-MS & ISO 17294-2:2017 & \\
\hline Ammonium ion & Spectrophotometry & ISO 7150-1:1984 & $0.02 \mathrm{mg} / \mathrm{L}$ \\
\hline Total Organic Carbon (TOC) & $\begin{array}{l}\text { Thermal oxidation, } \\
\text { IR detection }\end{array}$ & EN 1484:1997 & $0.3 \mathrm{mg} / \mathrm{L}$ \\
\hline Trihalomethanes (THMs) & Purge\&Trap-GC-MS & Hungarian standard 1484-5:1998 & $1.0 \mu \mathrm{g} / \mathrm{L}$ \\
\hline
\end{tabular}

${ }^{1}$ Modified to avoid interfering with the disinfectants: ZnS precipitate was filtered off and diluted with an equal volume of deionized water before the addition of the color-forming reagent. ${ }^{2}$ Measured against disinfectantcontaining blanks.

The total mineral content of water is a sum parameter expressing the total amount of dissolved ions, and was calculated according to Equation (1):

$$
\text { Total mineral content }=\frac{\mathrm{C}_{\mathrm{HCO}_{3}^{-}}}{2}+\text { evaporation residue }\left(180{ }^{\circ} \mathrm{C}\right)
$$

Analytical methods and standards used for the characterization of water samples are summarized in Table 1.

The effect of disinfectant treatment on the therapeutic components was expressed as the percentage difference of the mean concentrations measured in the treated and control samples. The significance of the difference between sample groups was analyzed by paired $t$-test at a $95 \%$ confidence level.

Analysis of disinfection byproducts

Chlorinated, brominated, and iodinated trihalomethanes (chloroform, bromodichloromethane, dibromochloromethane, bromoform, dichloroiodomethane, bromochloroiodomethane, dibromoiodomethane, diiodochloromethane, diiodobromomethane, iodoform) were measured. The ten trihalomethane (THM) compounds listed above are hereinafter referred to as $\mathrm{THM}_{10}$, and the iodinated ones as iTHM. THMs were measured by the Purge\&Trap gas chromatography-mass spectrometry method (GC-MS; 7890B GC, 7000C MS TripleQuad, 
Agilent, Santa Clara, CA, USA; Stratum Purge\&Trap, Teledyne Tekmar, Mason, OH, USA). Distribution of THM species was characterized by incorporation factor. Bromine incorporation factor (BIF); Equation (2) is defined by Gould as the ratio of the molar concentration of bromine incorporated into a given class of disinfection byproducts (DBPs; here $\left.\mathrm{THM}_{10}\right)$ to the molar concentration of DBPs in that class, as presented in Equation (2) [40]:

$$
\mathrm{BIF}=\frac{\mathrm{CHBrCl}_{2}+2 * \mathrm{CHBr}_{2} \mathrm{Cl}+3 * \mathrm{CHBr}_{3}+\mathrm{CHBrClI}+2 * \mathrm{CHBr}_{2} \mathrm{I}+\mathrm{CHBrI}_{2}}{\mathrm{CHCl}_{3}+\mathrm{CHBrCl}_{2}+\mathrm{CHBr}_{2} \mathrm{Cl}+\mathrm{CHBr}_{3}+\mathrm{CHCl}_{2} \mathrm{I}+\mathrm{CHBrClI}+\mathrm{CHBr}_{2} \mathrm{I}+\mathrm{CHClI}_{2}+\mathrm{CHBrI}_{2}+\mathrm{CHI}_{3}}
$$

For our analysis, incorporation factor was defined for iodine as well (IIF); Equation (3):

$$
\mathrm{IIF}=\frac{\mathrm{CHCl}_{2} \mathrm{I}+\mathrm{CHBrClI}+\mathrm{CHBr}_{2} \mathrm{I}+2 * \mathrm{CHClI}_{2}+2 * \mathrm{CHBrI}_{2}+3 * \mathrm{CHI}_{3}}{\mathrm{CHCl}_{3}+\mathrm{CHBrCl}_{2}+\mathrm{CHBr}_{2} \mathrm{Cl}+\mathrm{CHBr}_{3}+\mathrm{CHCl}_{2} \mathrm{I}+\mathrm{CHBrClI}+\mathrm{CHBr}_{2} \mathrm{I}+\mathrm{CHClI}_{2}+\mathrm{CHBrI}_{2}+\mathrm{CHI}_{3}}
$$

Chlorate and bromate ions were measured by ion chromatography (Dionex ICS-5000+, Thermo Scientific, Waltham, MA, USA).

Qualitative GC-MS fingerprint measurements were carried out to identify potential unknown disinfection byproducts. GC-MS fingerprints were prepared from $1 \mathrm{~L}$ of control and treated samples extracted with $3 \times 20 \mathrm{~mL}$ dichloromethane and adjusting the $\mathrm{pH}$ to 2, 7 and 10. The eluate was concentrated and analyzed by GC-MS (HP 6890 GC, HP 5973 MSD, Hewlett Packard, Palo Alto, CA, USA) in scan mode. The peaks were identified by Agilent software based on NIST MS spectra library.

\section{Results}

\subsection{Disinfection Efficacy}

The disinfection efficacy of the tested disinfectants was characterized by the logarithm of the removal rate (the reduction of colony forming units, CFU, compared to the untreated control).

The efficacy of hydrogen peroxide for E. coli elimination in therapeutic water was above four orders of magnitude at all concentrations, and log reduction values were between 4.60 and 5.01, exceeding the values measured for hypochlorite (3.83-4.93). However, its efficacy against Pseudomonas was significantly lower; mean log removal rates were 1.0, 2.5 and 3.9 for 30, 100 and $200 \mathrm{mg} / \mathrm{L}$ hydrogen peroxide, respectively (Figure 1). Sodium hypochlorite was more potent against Pseudomonas than the hydrogen peroxide-containing product; the average removal efficiency for this bacteria was between 3.44 and 4.09 for the tested concentrations.

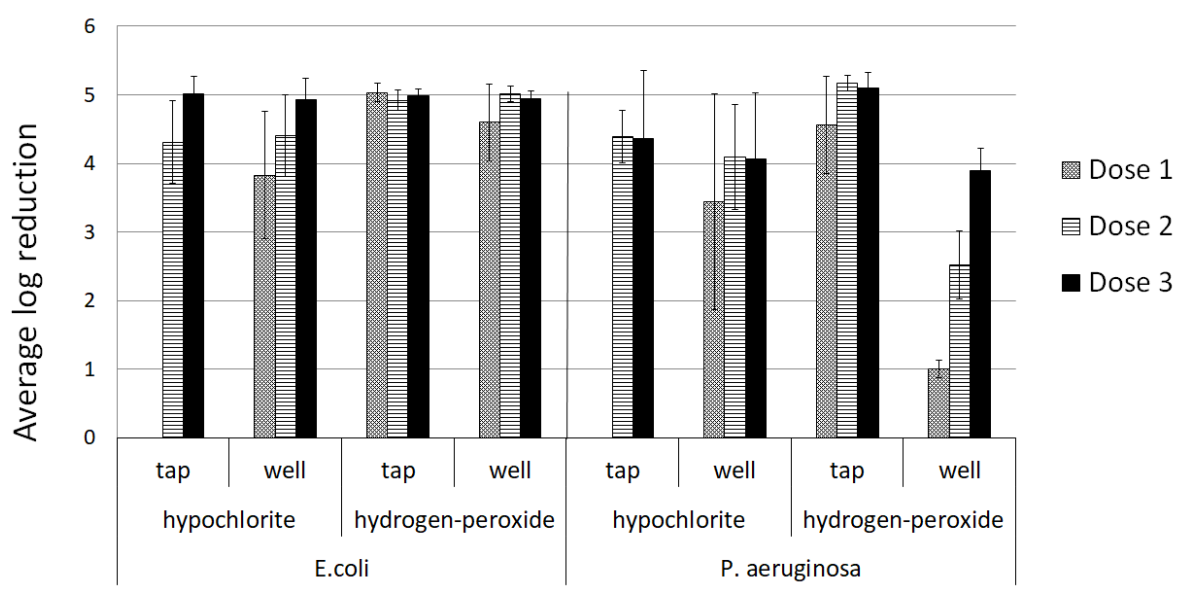

Figure 1. Efficacy of hypochlorite and hydrogen peroxide against E. coli and Pseudomonas aeruginosa in tap water and therapeutic well water, expressed as log removal rates. Tap: dechlorinated tap water; well: therapeutic water. Dose 1 = below breakpoint at hypochlorite $/ 30 \mathrm{mg} / \mathrm{L}$ hydrogen peroxide, Dose $2=0.5 \mathrm{mg} / \mathrm{L}$ free chlorine $/ 100 \mathrm{mg} / \mathrm{L}$ hydrogen peroxide, Dose $3=1 \mathrm{mg} / \mathrm{L}$ free chlorine/200 $\mathrm{mg} / \mathrm{L}$ hydrogen peroxide. 
In tap water, both disinfectants effectively removed the tested bacteria even at the lowest concentration. Average log reduction values in all cases exceeded four orders of magnitude (Figure 1). Hypochlorite reduced E. coli and P. aeruginosa counts by 4.31-5.01 and, 4.22-4.39 orders of magnitude, respectively; as the tap water did not contain ammonia, the lowest hypochlorite dose below breakpoint was not tested. For hydrogen peroxide, log reduction rates ranged from of 4.92-5.03 for E. coli and 4.55-5.17 for Pseudomonas.

Removal rates of E. coli were similar in both types of matrix regardless of the type of disinfectant. The disinfection efficiency for Pseudomonas was significantly better in tap water than in the therapeutic well water. However, using the hypochlorite-based disinfectant, the difference was not significant in either case; in order to reach the same free chlorine concentration in the therapeutic water, a larger amount of hypochlorite was required due to the excess quantity required for the oxidation of ammonia.

\subsection{Disinfection Byproducts}

\subsubsection{Disinfection Byproducts Generated during Hypochlorite Treatment}

\section{- Trihalomethanes $\left(\mathrm{THM}_{10}\right)$}

The total concentration of $\mathrm{THM}_{10}$ (chlorinated, brominated, and iodinated trihalomethanes) varied between 1.4-4.5 $\mathrm{g}$ /L (Figure 2a) in the treated therapeutic water. Mean concentration was higher above than below the breakpoint. However, the difference between below breakpoint and $0.5 \mathrm{mg} / \mathrm{L}$ free chlorine was not significant, possibly due to a high standard deviation at the latter dose. The effect of contact time was more pronounced; after $12 \mathrm{~h}, \mathrm{THM}_{10}$ concentration increased by $132 \%, 102 \%$, and $124 \%$ for increasing free chlorine doses compared to $1 \mathrm{~h}$ contact time. The most significant difference between the doses was the proportion of iodinated THMs. Below the breakpoint iodinated compounds were dominant, accounting for $74 \%$ and $85 \%$ of the total $\mathrm{THM}_{10}$ concentration at $1 \mathrm{~h}$ and $12 \mathrm{~h}$, respectively. Above the breakpoint, iodinated THMs were negligible compared to $\mathrm{THM}_{4}$ (the four regulated compounds) (Figure 2a).

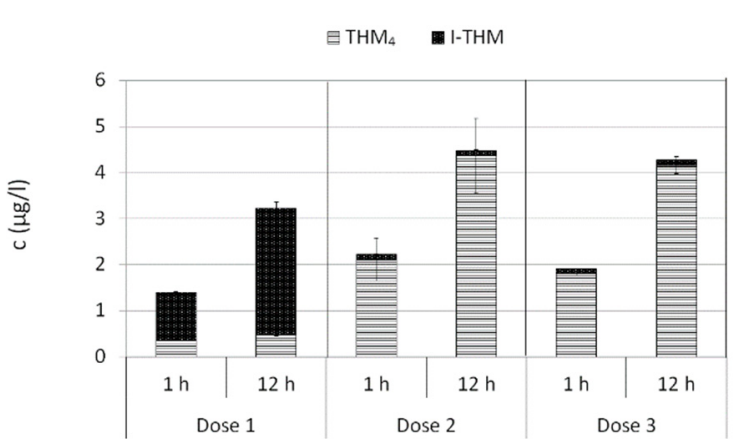

(a)

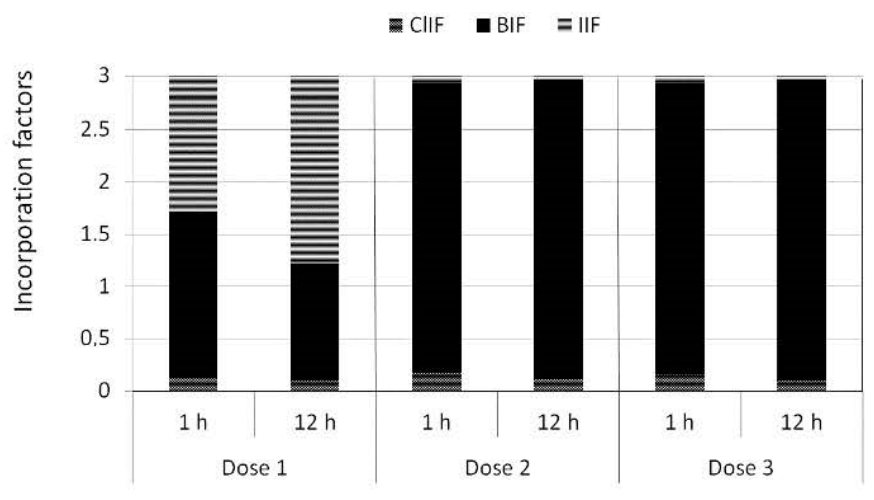

(b)

Figure 2. Chlorination byproducts of hypochlorite treatment in therapeutic water: (a) Concentration of total I-THM and $\mathrm{THM}_{4}$ compounds; (b) Incorporations factors for chlorine (CIIF), bromine (BIF), and iodine (IIF). Denotion of nominal concentrations: Dose $1=$ below breakpoint, Dose $2=0.5 \mathrm{mg} / \mathrm{L}$ free chlorine, Dose $3=1 \mathrm{mg} / \mathrm{L}$ free chlorine.

At the 0.5 and $1 \mathrm{mg} / \mathrm{L}$ free chlorine concentrations brominated compounds dominated. The most prevalent species was bromoform, accounting for $84-92 \%$ of the total $\mathrm{THM}_{10}$ concentration. Chloroform was not detected in any of the samples (Table 2). The halogen incorporation factors reflected this difference; BIF values for $\mathrm{THM}_{10}$ were high $(2.77$ and 2.78 of the total value 3), while CIIF (chlorine incorporation factor) and IIF were between 0.06-0.17 (Figure 2b). The effect of contact time was not significant; BIF value increased slightly further, by 3.2-3.5\%. Below the breakpoint, the distribution of THM species showed a very different picture. The most prevalent species were those containing only bromine 
and iodine $\left(\mathrm{CHBr}_{3}, \mathrm{CHBr}_{2} \mathrm{I}, \mathrm{CHBrI}_{2}, \mathrm{CHI}_{3}\right)$, of which iodoform became dominant at higher contact time (Table 2). The incorporation factors were in line with this observation; BIF was slightly higher than IIF at $1 \mathrm{~h}$, and the rate was reversed at the 12-h contact time (Figure $2 \mathrm{~b}$ ).

Table 2. Mean concentrations of $\mathrm{THM}_{10}$ compounds at hypochlorite treatments. The darker green color indicates an increasing concentration in the experiment.

\begin{tabular}{|c|c|c|c|c|c|c|c|c|c|c|}
\hline & \multicolumn{10}{|c|}{ Concentration $(\mu \mathrm{g} / \mathrm{L})$} \\
\hline & $\mathrm{CHCl}_{3}$ & $\mathrm{CHBrCl}_{2}$ & $\mathrm{CHBr}_{2} \mathrm{Cl}$ & $\mathrm{CHBr}_{3}$ & $\mathrm{CHCl}_{2} \mathrm{I}$ & $\mathrm{CHBrClI}$ & $\mathrm{CHBr}_{2} \mathrm{I}$ & $\mathrm{CHClI}_{2}$ & $\mathrm{CHBrI}_{2}$ & $\mathrm{CHI}_{3}$ \\
\hline Below breakpoint-1 $\mathrm{h}$ & 0.0 & 0.0 & 4.4 & 21.4 & 0.3 & 4.2 & 20.5 & 0.3 & 24.4 & 25.1 \\
\hline $0.5 \mathrm{mg} / \mathrm{L}$ free chlorine $-1 \mathrm{~h}$ & 0.0 & 1.1 & 9.4 & 84.2 & 0.2 & 2.1 & 3.2 & 0.2 & 0.3 & 0.3 \\
\hline $1 \mathrm{mg} / \mathrm{L}$ free chlorine $-1 \mathrm{~h}$ & 0.0 & 0.8 & 8.9 & 84.8 & 0.2 & 2.2 & 3.3 & 0.2 & 0.4 & 0.4 \\
\hline Below breakpoint-12 h & 0.0 & 0.0 & 2.2 & 12.3 & 0.1 & 2.3 & 15.2 & 2.8 & 20.7 & 44.5 \\
\hline $0.5 \mathrm{mg} / \mathrm{L}$ free chlorine $-12 \mathrm{~h}$ & 0.0 & 0.9 & 6.0 & 90.3 & 0.1 & 1.0 & 1.8 & 0.1 & 0.2 & 0.2 \\
\hline $1 \mathrm{mg} / \mathrm{L}$ free chlorine $-12 \mathrm{~h}$ & 0.0 & 0.6 & 5.4 & 91.3 & 0.1 & 1.0 & 1.7 & 0.1 & 0.2 & 0.2 \\
\hline
\end{tabular}

\section{- Chlorate ions}

Chlorate is formed through the degradation of hypochlorite during storage, not during the disinfection procedure. It has known adverse health effects, mainly oxidative damage to red blood cells [41]. Chlorate ions were detected in the hypochlorite-treated samples in concentrations proportional to the applied disinfectant dose (mean concentration 1.1, 1.5, $1.6 \mathrm{mg} / \mathrm{L}$, respectively), and concentrations was not affected by contact time or the matrix.

- Combined chlorine

Combined chlorine was generated from the reaction of hypochlorite with the ammonium content of the therapeutic test water. Its mean concentration below the breakpoint (after complete elimination of free chlorine) was $0.32 \mathrm{mg} / \mathrm{L}$. At higher doses of hypochlorite above the breakpoint, ammonia was completely consumed by hypochlorite in a rapid reaction taking approximately $10 \mathrm{~min}$. Combined chlorine concentration after the reaction was $0.05-0.1 \mathrm{mg} / \mathrm{L}$, close to the limit of detection.

\subsubsection{Disinfection Byproducts Generated during Hydrogen Peroxide Treatment}

In the comparison of fingerprint MS scans of the treated and untreated therapeutic water, only one compound, epichlorohydrin, was identified as unique to the treated water. The source of epichlorohydrin was probably the disinfectant, as it is a monomer of the quaternary ammonium compound (epichlorohydrin-dimethylamin polymer) used as an additive.

The organic matter content of the tested water (total organic carbon $(\mathrm{TOC})=1.1 \mathrm{mg} / \mathrm{L}$ ) was relatively low among Hungarian therapeutic waters. According to the database on the characteristics and composition of Hungarian therapeutic waters maintained by the Hungarian National Public Health Center (NPHC), the mean and median TOC concentration in Hungarian therapeutic waters is $12.1 \mathrm{mg} / \mathrm{L}$ and $5 \mathrm{mg} / \mathrm{L}$, respectively. However, the tested water does contain numerous different organic compounds. The diversity of the natural organic constituents of the water poses a challenge for identifying potential disinfection byproducts generated during treatment with the hydrogen peroxide-based product.

\subsection{Effect on Therapeutic Components \\ 3.3.1. Sulfide Ions}

Sulfide ions were found to be the most sensitive therapeutic component investigated in this study. The initial concentration $(0.7 \mathrm{mg} / \mathrm{L})$ decreased below the LOD $(0.1 \mathrm{mg} / \mathrm{L} ; \geq 86 \%$ elimination) after treatment in every case, even at the shortest contact time and lowest dose of either disinfectant. (Table 3) In aqueous solutions, sulfide speciates into compounds with different degrees of protonation. Due to the volatility of $\mathrm{H}_{2} \mathrm{~S}$, evaporation contributes to the loss of sulfide $[42,43]$. However, the results from multiple control experiments in the 
present study indicated that oxidation by the disinfectant is a more rapid reaction than evaporation. In the presence of either oxidant sulfide was eliminated within $10 \mathrm{~min}$, while without disinfectant the required time for complete removal was about $2 \mathrm{~h}$. Thus, during the 10 -min contact time a maximum of $14 \%$ of the loss can be attributed to evaporation, and the remaining $86 \%$ of the initial sulfur content is likely to be present in the solution as a different oxidized sulfur species. The main oxidation products of sulfide are elemental sulfur and sulfate ions $[28,29]$. The $\mathrm{pH}$ of the treated water $(\mathrm{Ph}=7.8)$ and the excess of the oxidizing agent promotes the formation of sulfate ions. However, quantitation of sulfate formed by oxidation was not possible because of the relatively small increase (maximum $2.1 \mathrm{mg} / \mathrm{L},<1 \%$ ) compared to the original sulfate concentration of the water (approximately $350 \mathrm{mg} / \mathrm{L})$.

Table 3. Mean concentrations of therapeutic components in control and treated samples.

\begin{tabular}{|c|c|c|c|c|c|c|c|c|c|}
\hline & \multirow{3}{*}{ Sample Type } & \multicolumn{2}{|c|}{ Disinfectant Target Concentration } & \multirow{2}{*}{$\begin{array}{c}\text { Sulfide } \\
\text { Ion }\end{array}$} & \multirow{2}{*}{$\begin{array}{l}\text { Iodide } \\
\text { Ion }\end{array}$} & \multirow{2}{*}{$\begin{array}{l}\text { Bromide } \\
\text { Ion }\end{array}$} & \multirow{2}{*}{ Lithium } & \multirow{2}{*}{ Silica } & \multirow{2}{*}{$\begin{array}{c}\text { Total } \\
\text { Mineral } \\
\text { Content }\end{array}$} \\
\hline & & Free Chlorine & Hydrogen Peroxide & & & & & & \\
\hline & & & & & $\mathrm{ng} / \mathrm{L}$ & & & & \\
\hline \multirow{7}{*}{ 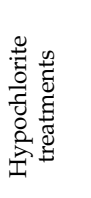 } & Control & $<0.05$ & & 0.7 & 1.27 & 7.03 & 0.45 & 15.6 & 1335 \\
\hline & Below breakpoint $-1 \mathrm{~h}$ & below breakpoint & & $<0.1$ & 0.39 & 6.87 & 0.44 & 15.7 & 1335 \\
\hline & Below breakpoint- $12 \mathrm{~h}$ & below breakpoint & & $<0.1$ & 0.29 & 7.00 & 0.45 & 15.6 & 1346 \\
\hline & $0.5 \mathrm{mg} / \mathrm{L}$ free chlorine $-1 \mathrm{~h}$ & 0.5 & & $<0.1$ & $<0.03$ & 7.01 & 0.45 & 15.9 & 1365 \\
\hline & $0.5 \mathrm{mg} / \mathrm{L}$ free chlorine $-12 \mathrm{~h}$ & 0.5 & & $<0.1$ & $<0.03$ & 6.87 & 0.42 & 15.6 & 1363 \\
\hline & $1 \mathrm{mg} / \mathrm{L}$ free chlorine $-1 \mathrm{~h}$ & 1 & & $<0.1$ & $<0.03$ & 6.98 & 0.44 & 15.7 & 1318 \\
\hline & $1 \mathrm{mg} / \mathrm{L}$ free chlorine $-12 \mathrm{~h}$ & 1 & & $<0.1$ & $<0.03$ & 6.97 & 0.44 & 15.5 & 1319 \\
\hline \multirow{7}{*}{ 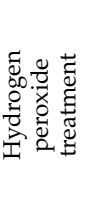 } & Control & & $<0.1$ & 0.7 & 1.24 & 7.03 & 0.49 & 16.6 & 1335 \\
\hline & $30 \mathrm{mg} / \mathrm{L}-1 \mathrm{~h}$ & & 30 & $<0.1$ & 1.16 & 6.83 & 0.48 & 16.4 & 1385 \\
\hline & $30 \mathrm{mg} / \mathrm{L}-12 \mathrm{~h}$ & & 30 & $<0.1$ & 1.12 & 6.78 & 0.47 & 16.5 & 1410 \\
\hline & $100 \mathrm{mg} / \mathrm{L}-1 \mathrm{~h}$ & & 100 & $<0.1$ & 1.16 & 6.76 & 0.46 & 16.9 & 1418 \\
\hline & $100 \mathrm{mg} / \mathrm{L}-12 \mathrm{~h}$ & & 100 & $<0.1$ & 1.17 & 6.73 & 0.46 & 16.6 & 1426 \\
\hline & $200 \mathrm{mg} / \mathrm{L}-1 \mathrm{~h}$ & & 200 & $<0.1$ & 1.12 & 6.54 & 0.46 & 16.6 & 1405 \\
\hline & $200 \mathrm{mg} / \mathrm{L}-12 \mathrm{~h}$ & & 200 & $<0.1$ & 1.20 & 6.54 & 0.46 & 16.3 & 1391 \\
\hline
\end{tabular}

\subsubsection{Iodide Ions}

Hydrogen peroxide treatment did not significantly affect the concentration of iodide ions (1.21-1.35 mg/L) (Table 3). The maximum difference between the mean concentrations of the treated and control samples was $9.8 \%$, and no correlation was observed between the disinfectant dose and the contact time.

In the samples treated with hypochlorite, a significant loss of iodide ions was observed. The lowest dose (below the breakpoint) reduced the iodide concentration by $70 \%$ and $77 \%$ after $1 \mathrm{~h}$ and $12 \mathrm{~h}$, respectively. Iodide was eliminated completely (to below the LOD of $0.01 \mathrm{mg} / \mathrm{L}$ ) at higher hypochlorite concentrations, regardless of the contact time. The main oxidation products of iodide under the test conditions were hypoiodite and, by its further oxidation, iodate [34]. End products were not detectable due to the high LOD $(2 \mathrm{mg} / \mathrm{L}$, which is higher than the theoretical calculated maximum amount of iodate that can be formed from the initial iodide ion content) of iodate with the IC method used in this matrix. The quantity of iodide incorporated into iTHMs (see Section 3.2.1) was negligible $(0.06-2.3 \mu \mathrm{g} / \mathrm{L}$, max. $0.18 \%)$.

\subsubsection{Bromide Ions}

Hydrogen peroxide treatment slightly reduced the initial concentration of bromide ions $(6.7-7.3 \mathrm{mg} / \mathrm{L})$, especially at higher disinfectant doses, with a maximum loss of $8.8 \%$ (Table 3). The differences between the treated and control samples and between the different contact times and disinfectant doses were not significant.

Hypochlorite treatment did not alter the concentration of bromide ions $(6.7-7.3 \mathrm{mg} / \mathrm{L})$; the maximum difference between the treated and control samples was $2.3 \%$. Neither disinfectant dose nor contact time had a significant effect. The quantity of bromide incorporated into THMs and iTHMs (see Section 3.2.1) was negligible compared to the initial amount present $(0.57-5.0 \mu \mathrm{g} / \mathrm{L}$, less than $0.1 \%)$. 


\subsubsection{Total Mineral Content}

The total mineral content (TMC) was not altered significantly by either disinfectant, regardless of the dose and contact time. The largest deviation from the control was 6.8\%.

\subsubsection{Metasilicic Acid}

No significant decrease in the initial silicon concentration $(16 \mathrm{mg} / \mathrm{L} \mathrm{Si})$ was observed after disinfection. The maximum deviation from the control was $2.1 \%$ and $1.7 \%$ using hydrogen peroxide and hypochlorite, respectively. There were no significant differences between the different doses or contact times with either disinfectant.

\subsubsection{Lithium}

The initial mean concentration of lithium $(0.45 \mathrm{mg} / \mathrm{L})$ was not affected by the applied disinfectants. There was no significant difference between the untreated and treated samples in either case, regardless of the applied dose or contact time. The maximum deviation was $6.3 \%$ and $5.7 \%$ for hydrogen peroxide and hypochlorite, respectively.

\section{Discussion}

\subsection{Disinfection Efficacy}

Hypochlorite proved to be effective for the elimination of E. coli and Pseudomonas aeruginosa in the tested therapeutic water at all applied concentrations, while the efficacy of the hydrogen peroxide-based product against Pseudomonas was only sufficiently effective at $200 \mathrm{mg} / \mathrm{L}$ and removal rates dropped with decreasing concentrations. The efficacy of disinfection proved to be dependent on the matrix; in the tap water control, the difference in the disinfection efficacy of the two products was not significant (paired $t$-test, $95 \%$ confidence level). Water quality variables can influence the efficacy of disinfection in several ways, including through reducing available disinfectant quantity (constant reagent demand due to oxidizable compounds), influencing the activity through altering chemical properties or reaction rate of disinfectants $(\mathrm{pH}$, temperature), or by increasing the resistance of microorganisms (presence of particles, conditions promoting biofilm formation) [44]. The efficacy of sodium hypochlorite has been investigated in several studies, and it is known to be dependent on temperature and $\mathrm{pH}[45,46]$ while being unaffected by high mineral content [47]. The latter was confirmed in the present study. However, factors determining the efficacy of hydrogen peroxide and the quaternary ammonium compound have been less widely studied.

Based on the results, $P$. aeruginosa may present an important risk factor when using hydrogen peroxide-based products. P. aeruginosa is a well-known waterborne pathogen associated with acute folliculitis in pools, known as "hot tub rash" [48], and is an indicator of biofilm formation potential. In our case study of disinfected therapeutic pools in Hungary, $P$. aeruginosa was the most common reason for non-compliance in pools treated with hydrogen peroxide [38]. As efficacy is considerably reduced with decreasing concentration, maintaining the appropriate level of disinfectant is especially important in waters with significant matrix effects. Close attention should be paid to preventing biofilm formation, which can support the growth of microorganisms and protect them from disinfectants. Effective preventative measures include regular shock disinfection treatments and the introduction of additional disinfectants (e.g., chlorine dioxide) at high risk points such as filters $[49,50]$.

\subsection{Disinfection Byproducts}

The use of hypochlorite in disinfection is known to be associated with the formation of disinfection byproducts where precursor organic or nitrogen compounds are present [51]. While the phenomenon is well-characterized in drinking water and pool water, limited data are available for thermal mineral waters used for therapeutic bathing.

Of the measured $\mathrm{THM}_{10}$ compounds, concentrations of the regulated $\mathrm{THM}_{4}$ molecules were below the parametric values of the Hungarian regulations ( $50 \mu \mathrm{g} / \mathrm{L}$ for the sum of 
$\mathrm{THM}_{4}$ ). Regulation has not yet been established for I-THM compounds, either in Hungary or worldwide. The most significant THM in swimming pools is usually chloroform [52]; however, in our experiments brominated and iodinated compounds dominated. Because their precursors, bromide and iodide ions [53], are common in therapeutic waters (maximum 25 and $22 \mathrm{mg} / \mathrm{L}$, median 0.65 and $0.26 \mathrm{mg} / \mathrm{L}$, respectively, according to the NPHC database) this phenomenon can be considered general in the field of therapeutic water treatment. Species distribution showed a very different picture at doses below and above the breakpoint. In accordance with previous studies, below the breakpoint iodinated compounds predominated [54]. In the presence of free chlorine, the proportion of brominated compounds was significant.

There are open questions about the health effects of THMs; however, several species have been associated with negative health impacts including genotoxicity and carcinogenicity. Among $\mathrm{THM}_{4}$ compounds, harmful effects increase through oral exposure with the amount of incorporated bromine, with iodinated THMs are considered to represent the most genotoxic group $[55,56]$. In swimming pools, unacceptable level of health risk due to THMs have been identified mainly due to inhalation of chloroform evaporating from the water [52]. Volatility of THMs, and therefore exposure by inhalation, decrease with increasing bromide and iodide content; lower THM concentrations in the air may reduce the overall health risk. However, among the examples of $\mathrm{THM}_{4}$ bromoform permeates most readily through the skin, while chloroform is the least permeable [57] and no data are currently available for iodinated compounds. Thus, the health risks of dermal absorption may be higher.

Of the investigated disinfection byproducts, combined chlorine levels were below the parametric value required by the Hungarian regulations $(0.5 \mathrm{mg} / \mathrm{L})$ in all experiments. The formation of combined chlorine is common in chlorinated pool water due to the presence of nitrogen precursor chemicals of human origin, particularly ammonium ions and urea (which can be readily decomposed to ammonium ions) in the $0.1-5 \mathrm{mg} / \mathrm{L}$ concentration range $[6,58,59]$. However, thermal waters from deep aquifers often contain high concentration of ammonium ions naturally from geological origins in addition to bather-derived contamination. According to the NPHC database, the ammonium ion concentration of Hungarian therapeutic waters can reach a maximum of $57 \mathrm{mg} / \mathrm{L}$ (median $5.6 \mathrm{mg} / \mathrm{L}$ ), and is absent $(<0.02 \mathrm{mg} / \mathrm{L})$ only in $2 \%$ of such waters. If hypochlorite is underdosed (i.e., the applied dose of hypochlorite is insufficient for the complete oxidation of the ammonia, as simulated with the lowest dose in the present study) no free chlorine will be present in the treated water for disinfection. If the hypochlorite dose is sufficient for microbial safety, the presence of combined chlorine residual is inevitable and can reach a high concentration if initial ammonium levels are high, as observed in a case study of disinfected spas [38]). Combined chlorine consists of different organic and inorganic chloramines. While monochloramine has a small disinfectant effect, it is not as effective as free chlorine [60]; several other chloroamine compounds have adverse health impacts, such as causing asthma [61,62]. As they are often volatile, the risk to health will be present in sitting pools, including therapeutic pools.

In addition to the formation of chloramines, other problems arise if the ammonia concentration is high in the water; costs are higher due to increased consumption of chemicals, and maintaining a proper disinfectant level is more difficult or requires complex technology. The most common method of removing ammonia is to use breakpoint chlorination; this process requires vigorous oxidation with a large excess of chemicals followed by filtration on activated carbon, which fundamentally changes the composition of the water.

Measured concentrations of chlorate ions were proportional to the applied dose, indicating their formation by the slow disproportionation of hypochlorite over time during storage, in line with the literature [41,63]. All measured values were below the WHO guideline value for pools $(3 \mathrm{mg} / \mathrm{L})$. Information on the detrimental health effects of chlorate is limited; oxidative damage to red blood cells is the primary concern [41]. As the main exposure route for chlorate is through oral ingestion, the risk may be reduced by the 
fact that therapeutic pools are used primarily as sitting pools, and thus water ingestion is limited.

When assessing the health effects of chlorinated bathing water, the general conclusion is that the beneficial effects of exercise (swimming) outweigh the risks posed by byproducts $[6,64]$. In therapeutic sitting pools, the beneficial effect of exercise cannot prevail. A study comparing the benefits of spa pools with the risks posed by byproducts has not yet been conducted. Further water and air measurements of disinfected therapeutic pools and risk assessment are necessary in order to quantify the health effects.

The use of hydrogen peroxide-based disinfectants is less common, and the related literature is scarce and mainly focuses on combined methods such as UV + hydrogen-peroxide or advanced oxidation processes. In our experiments, no DBPs were identified that would be produced from the reaction of hydrogen peroxide and the natural organic compounds in the water. The only compound introduced during treatment was epichlorohydrin, which is likely to originate from a secondary active ingredient in the disinfectant, epichlorohydrindimethylamin polymer. Epichlorohydrin is a possible human carcinogen [65] and a quaternary ammonium biocide, and is currently under review in the EU Biocides Review Programme, by the end of which more information on this issue is expected.

Our measurements are only the first step towards understanding byproduct formation in hydrogen peroxide treatment. Further research is necessary in order to identify potential byproducts, and assess their health effects.

\subsection{Effects on Therapeutic Components}

Both hydrogen peroxide and hypochlorite have oxidative properties, and therefore can react with oxidizable components in water. Both disinfectants have been previously shown to oxidize sulfide [26,28,29], bromide [31-33], and iodide ions [34-37], though the reaction conditions were not always the same as in therapeutic waters.

During our experiments, the results for hypochlorite treatment were in line with these findings, except with respect to bromide ions, where no significant decrease was measured. Hypochlorite is known to react with bromide ions in a highly $\mathrm{pH}$-dependent reaction ( $\mathrm{HOCl}$ being $10^{6}$ times more reactive than $\mathrm{OCl}^{-}$), mainly producing hypobromite ions $\left(\mathrm{OBr}^{-}\right)$[31,66]. The reaction rate is five orders of magnitude lower than that of the oxidation of iodide ions [53], which may explain the observed differences. During our case study assessing the application of disinfectants to therapeutic spa waters, the concentration of bromide ions decreased considerably in the pools compared to untreated therapeutic well water, which can possibly be explained by the longer contact time and continuous disinfectant dosing applied in circulated pools [38].

Dosing with the hydrogen peroxide-based product reduced only the concentration of sulfide ions, with bromide, and iodide ion concentrations remaining unchanged; this is in line with the results of on-site measurements in spas using this product for disinfection [38]. Though hydrogen peroxide is a stronger oxidant $\left(\mathrm{E}_{0}=1.76 \mathrm{~V}\right)$ than hypochlorite $\left(\mathrm{E}_{0}=0.89 \mathrm{~V}\right)$, its reactions can be kinetically inhibited at near-neutral $\mathrm{pH}$ [67]. For example, at acidic $\mathrm{pH}$, peroxide is able to oxidize bromide ions, while at neutral $\mathrm{pH}$ this reaction is much less significant [68].

For the other therapeutic components, reactions with the disinfectants were not expected based on their chemical properties, and this hypothesis was confirmed by the results. The main ions of the tested waters contributing to the total mineral content were $\mathrm{Na}^{+}, \mathrm{Ca}^{2+}$, $\mathrm{Mg}^{2+}, \mathrm{Cl}^{-}, \mathrm{SO}_{4}{ }^{2-}$, and $\mathrm{HCO}_{3}{ }^{-}$. These components are typically not very reactive, and are not known to react with hydrogen peroxide or hypochlorite under the study conditions. Silicon can exist in water in various forms, dissolved as acids or hydroxides or as polymers, colloids, or particles [69]. As silicon is usually present in oxidized form in these compounds, it is unlikely to react with oxidants. Lithium is not oxidizable under the test conditions [70].

Based on the NPHC therapeutic waters database, total mineral content is the most commonly-met criteria for classification as mineral water in Hungary; in 88\% of currentlycertified therapeutic well waters it exceeds $1000 \mathrm{mg} / \mathrm{L}$, the value required for classification. 
For $42 \%$, this is the sole basis of classification. Many contain metasilicic acid and iodide ions as well (28.5\% and $26.1 \%$, respectively), while bromide ions and sulfide ions are slightly less characteristic (both present in $17.5 \%$ of the waters). Only $7.9 \%$ of all therapeutic waters contain lithium, and only 4.3 and $0.4 \%$ contain free carbon dioxide and radon, respectively, in sufficient quantity for certification. The presence of sensitive therapeutic components can thus be a limiting factor for the application of sodium hypochlorite and hydrogen peroxide-based agent in $44 \%$ and $18 \%$ of domestic therapeutic waters, respectively.

Although legislation links the certification of therapeutic waters to the presence of allegedly biologically-active components, the therapeutic effect of waters is connected to the water as a whole, including its temperature and physical comfort. Dose-response relationships and the mechanisms of action for the specified components are mostly unclear, except for some studies on sulfide [71,72]. Indeed, most studies in evidence-based balneotherapy have failed to establish a connection to the exact chemical composition. Therefore, changes in chemical state (oxidation) do not necessarily lead to a reduction in the therapeutic effect. Clinical trials with disinfected water would be required to assess this question. However, the formation of harmful disinfection by-products is an important consideration for the selection of disinfectants.

\subsection{Applicability of the Tested Disinfectants for the Treatment of Therapeutic Waters}

Therapeutic waters are diverse in composition, and there can be no universal solution for their treatment. As microbial water quality in pools must be ensured, various methods should be tested in order to find appropriate treatments. The proposed methods for disinfecting thermal and therapeutic waters available in the literature are mainly physical procedures [4,12-14]. However, based on our results chemical disinfection can be applied to particular therapeutic waters. The respective advantages and limitations of several possible methods are presented in Table 4.

Table 4. Characteristics of disinfection methods investigated in the present study and recommended in the literature for therapeutic water treatment.

\begin{tabular}{|c|c|c|}
\hline Treatment & Advantages & Limitations and Difficulties in Therapeutic Water Treatment \\
\hline $\begin{array}{l}\text { Hydrogen peroxide-based } \\
\text { product }\end{array}$ & $\begin{array}{l}\text { Fewer toxic byproducts, therapeutic } \\
\text { components unaffected (except for sulfide), } \\
\text { more acceptable to bathers ("chlorine-free") }\end{array}$ & $\begin{array}{l}\text { Medium costs, } \\
\text { close control of residual disinfectant concentration is needed } \\
\text { (matrix effect), possible non-identified byproducts }\end{array}$ \\
\hline Sodium hypochlorite & $\begin{array}{l}\text { Low costs, convenient, easy handling, high } \\
\text { efficacy }\end{array}$ & $\begin{array}{l}\text { Toxic byproducts, dosing difficulties and excess demand in the } \\
\text { presence of ammonia, loss of therapeutic components sulfide } \\
\text { and iodide }\end{array}$ \\
\hline UV treatment [12] & Low costs, high efficacy, no chemical dosing & No residual effect, fouling of lamps, toxic byproducts \\
\hline Ultrafiltration [13] & $\begin{array}{l}\text { Composition remains nearly unaffected, no } \\
\text { byproduct formation }\end{array}$ & $\begin{array}{c}\text { No residual effect, fouling of membrane, expertise is required } \\
\text { for operation }\end{array}$ \\
\hline Nanomaterials [14] & No chemical dosing, photocatalytic effect & Higher costs, may fundamentally change composition \\
\hline
\end{tabular}

Taking all factors (disinfection efficacy, byproduct formation, reaction with the specified components) into account and assessing the results against the national database of therapeutic waters, hypochlorite is only suitable for the treatment of about $2 \%$ of certified waters, mainly due to the presence of ammonia and to a lesser extent organic matter content. Hydrogen peroxide is more widely applicable; the chemical composition of $82 \%$ of the therapeutic waters is compatible with disinfection by this agent. The observed decreased disinfection efficacy of the hydrogen peroxide-based product in therapeutic water at lower concentrations means that close attention to appropriate dosing is required in practice.

\subsection{Strengths and Limitations of this Study}

This study presents a complex approach to the effects of chemical disinfection on therapeutic waters, investigating the ability to ensure microbial safety as well as the chemical risks and the fate of the therapeutic components. 
Laboratory experiments were carried out with therapeutic water representing the composition of the majority of Hungarian therapeutic waters. Thus, these findings can be applied to many other therapeutic pools. The applied doses and contact times were identical to those used in practice. Therefore, the results can be easily translated into practical application by pool operators.

However, future work remains necessary in order to extend the scope of the study to waters with different compositions. For instance, the possible effects of iron and manganese were not addressed in the present study, as the test water did not contain them in significant concentrations. These components can react with both hypochlorite and hydrogen peroxide, although they may be a less significant limiting factor than ammonia as they are typically present in lower amounts (median 0.11 and $0.01 \mathrm{mg} / \mathrm{L}$, maximum 6.9 and $0.74 \mathrm{mg} / \mathrm{L}$, respectively) and are often removed during pretreatment even in pools operating without disinfection.

The current study was based on laboratory model experiments; however, in everyday practice other factors could affect water quality and the effectiveness of water treatment technologies. For example, in our series of experiments disinfectants were administered in a single dose, while in practice disinfectant dosing (as well as the release of contaminants from both the environment and bathers) is continuous. Laboratory experiments should be considered complementary to on-site case studies in disinfected therapeutic pools [38].

\section{Conclusions}

Based on our results, chemical disinfection with hydrogen peroxide and sodium hypochlorite can be applied to certain therapeutic waters, taking their respective limitations into account.

The two tested disinfectants did not react with most alleged therapeutic components, and only sulfide ions and (when using hypochlorite) iodide ions were observed to be eliminated to some extent. While the impact on water composition and especially on the components considered biologically active are the main reasons for forgoing disinfection, our data suggest that this is not the primary concern. The formation of disinfection byproducts which pose a risk to bathers' health as well as the matrix-dependent loss of disinfection efficacy are more serious limitations. The former mainly arose when using hypochlorite, while the latter is a problem for hydrogen peroxide-based products. Presumptive byproducts generated during treatment with hydrogen peroxide-based disinfectant were identified, although the characterization of these compounds and their health effects require further research. Selection of a water treatment procedure should always take into account the local conditions, including water quality characteristics, bather load, and management practices. It should be noted that even with disinfection, good operational practices and hygienic education of bathers are essential to ensuring adequate water quality in therapeutic pools.

Author Contributions: Conceptualization, D.G., G.Z. and M.V.; Data curation, D.G.; Formal analysis, D.G. and E.R.; Investigation, D.G. and E.R.; Methodology, D.G. and E.R.; Supervision, G.Z. and M.V.; Writing—original draft, D.G.; Writing—review \& editing, M.V. All authors have read and agreed to the published version of the manuscript.

Funding: This research received no external funding.

Institutional Review Board Statement: Not applicable.

Informed Consent Statement: Not applicable.

Data Availability Statement: All data presented in this study are contained within the article.

Acknowledgments: We acknowledge the contribution and help of Budapest Spas cPlc. The authors are grateful to thesis workers and colleagues for all of their help in performing the analytical measurements.

Conflicts of Interest: The authors declare no conflict of interest. 


\section{References}

1. Bender, T.; Bálint, G.; Prohászka, Z.; Géher, P.; Tefner, I.K. Evidence-based hydro- and balneotherapy in Hungary-a systematic review and meta-analysis. Int. J. Biometeorol. 2014, 58, 311-323. [CrossRef] [PubMed]

2. Falagas, M.E.; Zarkadoulia, E.; Rafailidis, P.I. The therapeutic effect of balneotherapy: Evaluation of the evidence from randomised controlled trials. Int. J. Clin. Pract. 2009, 63, 1068-1084. [CrossRef] [PubMed]

3. Barna, Z.; Kádár, M. The risk of contracting infectious diseases in public swimming pools. A review. Ann. Ist. Super. Sanita 2012, 48, 374-386. [CrossRef] [PubMed]

4. Costa, J.; da Costa, M.S.; Veríssimo, A. Colonization of a therapeutic spa with Legionella spp: A public health issue. Res. Microbiol. 2010, 161, 18-25. [CrossRef]

5. Walczak, M.; Krawiec, A.; Lalke-Porczyk, E. Legionella pneumophilla bacteria in a thermal saline bath. Ann. Agric. Environ. Med. 2013, 20, 649-652.

6. World Health Organization Guidelines for safe recreational water environments: Volume 2. Swimming pools and similar environments. World Health Organ. 2006, 2, 146.

7. Cinzia Germinario An outbreak of pneumonia in a thermal water spa contaminated with Pseudomonas aeruginosa: An epidemiological and environmental concern. Afr. J. Microbiol. Res. 2012, 6, 1978-1984. [CrossRef]

8. Heggie, T.W. Swimming with death: Naegleria fowleri infections in recreational waters. Travel Med. Infect. Dis. 2010, 8, 201-206. [CrossRef]

9. Kapitány, R.; Galambos, A.; Danku, N.; Boncz, I.; Pusztafalvi, H. Microbiological, Chemical Analysis and Comparison of Public Bath Waters in Baranya County Between 2010-2016. Value Health 2017, 20, A494-A495. [CrossRef]

10. Vargha, M.; Roka, E.; Barna, Z.; Kiss, C.; Kern, A. Microbiological water quality of Hungarian baths. In Proceedings of the Dissertations of the XXXIII. National Travelling Congress of the Hungarian Hydrological Society, Szombathely, Hungary, 1-3 July 2015; ISBN 978-963-8172-34-1. (In Hungarian).

11. Hungarian Ministerial Decree of the Minister of Health on the Natural Medicinal Factors. 1999. Available online: https: / / www.ecolex.org/details/legislation/act-no-cliv-of-1997-on-health-lex-faoc030586/ (accessed on 17 February 2022).

12. Sisti, M.; Pieretti, B.; De Santi, M.; Brandia, G. Inactivation of pathogenic dermatophytes by ultraviolet irradiation in swimming pool thermal water. Int. J. Environ. Health Res. 2014, 24, 412-417. [CrossRef]

13. Leoni, E.; Sanna, T.; Zanetti, F.; Dallolio, L. Controlling Legionella and Pseudomonas aeruginosa re-growth in therapeutic spas: Implementation of physical disinfection treatments, including UV/ultrafiltration, in a respiratory hydrotherapy system. J. Water Health 2015, 13, 996-1005. [CrossRef] [PubMed]

14. Margarucci, L.M.; Romano Spica, V.; Gianfranceschi, G.; Valeriani, F. Untouchability of natural spa waters: Perspectives for treatments within a personalized water safety plan. Environ. Int. 2019, 133, 105095. [CrossRef] [PubMed]

15. Tartanson, M.A.; Soussan, L.; Rivallin, M.; Chis, C.; Penaranda, D.; Lapergue, R.; Calmels, P.; Faur, C. A new silver based composite material for SPA water disinfection. Water Res. 2014, 63, 135-146. [CrossRef] [PubMed]

16. Andreozzi, R.; Caprio, V.; Insola, A.; Marotta, R. Advanced oxidation processes (AOP) for water purification and recovery. Catal. Today 1999, 53, 51-59. [CrossRef]

17. Zarei, A.; Biglari, H.; Mobini, M.; Dargahi, A.; Ebrahimzadeh, G.; Narooie, M.R.; Mehrizi, E.A.; Yari, A.R.; Mohammadi, M.J.; Baneshi, M.M.; et al. Disinfecting poultry slaughterhouse wastewater using copper electrodes in the electrocoagulation process. Pol. J. Environ. Stud. 2018, 27, 1907-1912. [CrossRef]

18. Afsharnia, M.; Kianmehr, M.; Biglari, H.; Dargahi, A.; Karimi, A. Disinfection of dairy wastewater effluent through solar photocatalysis processes. Water Sci. Eng. 2018, 11, 214-219. [CrossRef]

19. Ilyas, H.; Masih, I.; van der Hoek, J.P. Disinfection methods for swimming pool water: Byproduct formation and control. Water 2018, 10, 797. [CrossRef]

20. Lee, J.; Jun, M.J.; Lee, M.H.; Lee, M.H.; Eom, S.W.; Zoh, K.D. Production of various disinfection byproducts in indoor swimming pool waters treated with different disinfection methods. Int. J. Hyg. Environ. Health 2010, 213, 465-474. [CrossRef]

21. Zwiener, C.; Richardson, S.D.; DeMarini, D.M.; Grummt, T.; Glauner, T.; Frimmel, F.H. Drowning in disinfection byproducts? Swimming pool water qualtiy. Water 2007, 34, 42-46. [CrossRef]

22. Drogui, P.; Elmaleh, S.; Rumeau, M.; Bernard, C.; Rambaud, A. Hydrogen peroxide production by water electrolysis: Application to disinfection. J. Appl. Electrochem. 2001, 31, 877-882. [CrossRef]

23. McDonnell, G. The Use of Hydrogen Peroxide for Disinfection and Sterilization Applications. In PATAI'S Chemistry of Functional Groups; Wiley Online Library: Hoboken, NJ, USA, 2014.

24. Pedahzur, R.; Lev, O.; Fattal, B.; Shuval, H.I. The interaction of silver ions and hydrogen peroxide in the inactivation of E. coli: A preliminary evaluation of a new long acting residual drinking water disinfectant. Water Sci. Technol. 1995, 31, 123-129. [CrossRef]

25. Valeriani, F.; Margarucci, L.M.; Spica, V.R. Recreational use of spa thermal waters: Criticisms and perspectives for innovative treatments. Int. J. Environ. Res. Public Health 2018, 15, 2675. [CrossRef]

26. Cadena, F.; Peters, R.W. Evaluation of chemical oxidizers for hydrogen sulfide control. J. Water Pollut. Control Fed. 1988, 60, $1259-1263$.

27. Millero, F.J.; LeFerriere, A.; Fernandez, M.; Hubinger, S.; Hershey, J.P. Oxidation of hydrogen sulfide with hydrogen peroxide in natural waters. Environ. Sci. Technol. 1989, 23, 209-213. [CrossRef] 
28. Choppin, A.R.; Faulkenberry, L.C. The Oxidation of Aqueous Sulfide Solutions by Hypochlorites. J. Am. Chem. Soc. 1937, 59, 2203-2207. [CrossRef]

29. Hoffmann, M.R. Kinetics and Mechanism of Oxidation of Hydrogen Sulfide by Hydrogen Peroxide in Acidic Solution. Environ. Sci. Technol. 1977, 11, 61-66. [CrossRef]

30. Azizi, M.; Biard, P.F.; Couvert, A.; Ben Amor, M. Competitive kinetics study of sulfide oxidation by chlorine using sulfite as reference compound. Chem. Eng. Res. Des. 2015, 94, 141-152. [CrossRef]

31. Kumar, K.; Margerum, D.W. Kinetics and Mechanism of General-Acid-Assisted Oxidation of Bromide by Hypochlorite and Hypochlorous Acid. Inorg. Chem. 1987, 26, 2706-2711. [CrossRef]

32. Bray, W.C.; Livingston, R.S. The catalytic decomposition of hydrogen peroxide in a bromine-bromide solution, and a study of the steady state. J. Am. Chem. Soc. 1923, 45, 1251-1271. [CrossRef]

33. Bray, W.C.; Livingston, R.S. The rate of oxidation of hydrogen peroxide by bromine and its relation to the catalytic decomposition of hydrogen peroxide in a bromine-bromide solution. J. Am. Chem. Soc. 1928, 50, 1654-1665. [CrossRef]

34. Bichsel, Y.; Von Gunten, U. Oxidation of iodide and hypoiodous acid in the disinfection of natural waters. Environ. Sci. Technol. 1999, 33, 4040-4045. [CrossRef]

35. Kumar, K.; Day, R.A.; Margerum, D.W. Atom-Transfer Redox Kinetics: General-Acid-Assisted Oxidation of Iodide by Chloramines and Hypochlorite. Inorg. Chem. 1986, 25, 4344-4350. [CrossRef]

36. Liebhafsky, H.A. The catalytic decomposition of hydrogen peroxide by the iodine-iodide couple at $25^{\circ}$. J. Am. Chem. Soc. 1932, 54, 1792-1806. [CrossRef]

37. Schmitz, G. The oxidation of iodine to iodate by hydrogen peroxide. Phys. Chem. Chem. Phys. 2001, 3, 4741-4746. [CrossRef]

38. Gere, D.; Róka, E.; Erdélyi, N.; Bufa-Dörr, Z.; Záray, G.; Vargha, M. Disinfection of therapeutic water-balancing risks against benefits: Case study of Hungarian therapeutic baths on the effects of technological steps and disinfection on therapeutic waters. $J$. Water Health 2021, 20, 92-102. [CrossRef] [PubMed]

39. United States Environmental Protection Agency. Alternative Disinfectants and Oxidants Guidance Manual; United States Environmental Protection Agency: Washington, DC, USA, 1999.

40. Symons, J.M.; Krasner, S.W.; Simms, L.A.; Sclimenti, M. Measurement of THM and precursor concentrations revisited: The effect of bromide ion. J. / Am. Water Work. Assoc. 1993, 85, 51-62. [CrossRef]

41. World Health Organization, Chlorite and Chlorate in Drinking Water: Background Document for Development of WHO Guidelines for Drinking-Water Quality. 2005, p. 31. Available online: https://www.who.int/water_sanitation_health/dwq/ chemicals / chlorateandchlorite0505.pdf (accessed on 17 February 2022).

42. Balls, P.W.; Liss, P.S. Exchange of H2S between water and air. Atmos. Environ. 1983, 17, 735-742. [CrossRef]

43. Suleimenov, O.M.; Krupp, R.E. Solubility of hydrogen sulfide in pure water and in $\mathrm{NaCl}$ solutions, from 20 to $320{ }^{\circ} \mathrm{C}$ and at saturation pressures. Geochim. Cosmochim. Acta 1994, 58, 2433-2444. [CrossRef]

44. Barbeau, B.; Desjardins, R.; Mysore, C.; Prévost, M. Impacts of water quality on chlorine and chlorine dioxide efficacy in natural waters. Water Res. 2005, 39, 2024-2033. [CrossRef]

45. Fitzgerald, G.P.; DerVartanian, M.E. Factors Influencing the Effectiveness of Swimming Pool Bactericides. Appl. Microbiol. 1967, 15, 504-509. [CrossRef]

46. Barbeau, B.; Huffman, D.; Mysore, C.; Desjardins, R.; Prévost, M. Examination of discrete and counfounding effects of water quality parameters during the inactivation of MS2 phages and Bacillus subtilis spores with free chlorine. J. Environ. Eng. Sci. 2004, 3, 255-268. [CrossRef]

47. Swanson, S.; Fu, T.J. Effect of water hardness on efficacy of sodium hypochlorite inactivation of Escherichia coli O157:H7 in water. J. Food Prot. 2017, 80, 497-501. [CrossRef] [PubMed]

48. SEGNA, K.G.; KOCH, L.H.; WILLIAMS, J.V. “Hot Tub” Folliculitis from a NonChlorinated Children's Pool. Pediatr. Dermatol. 2011, 28, 590-591. [CrossRef]

49. Rice, S.A.; Van Den Akker, B.; Pomati, F.; Roser, D. A risk assessment of Pseudomonas aeruginosa in swimming pools: A review. J. Water Health 2012, 10, 181-196. [CrossRef]

50. Guida, M.; Di Onofrio, V.; Gallè, F.; Gesuele, R.; Valeriani, F.; Liguori, R.; Romano Spica, V.; Liguori, G. Pseudomonas aeruginosa in swimming pool water: Evidences and perspectives for a new control strategy. Int. J. Environ. Res. Public Health 2016, 13, 919. [CrossRef]

51. Chowdhury, S.; Al-hooshani, K.; Karanfil, T. Disinfection byproducts in swimming pool: Occurrences, implications and future needs. Water Res. 2014, 53, 68-109. [CrossRef] [PubMed]

52. Pándics, T.; Hofer, Á.; Dura, G.; Vargha, M.; Szigeti, T.; Tóth, E. Health risk of swimming pool disinfection by-products: A regulatory perspective. J. Water Health 2018, 16, 947-957. [CrossRef]

53. Hua, G.; Reckhow, D.A.; Kim, J. Effect of Bromide and Iodide Ions on the Formation and Speciation of Disinfection Byproducts during Chlorination. Environ. Sci. Technol. 2006, 40, 3050-3056. [CrossRef]

54. Liu, Z.; Lin, Y.L.; Xu, B.; Hu, C.Y.; Wang, A.Q.; Gao, Z.C.; Xia, S.J.; Gao, N.Y. Formation of iodinated trihalomethanes during breakpoint chlorination of iodide-containing water. J. Hazard. Mater. 2018, 353, 505-513. [CrossRef]

55. Richardson, S.D.; Plewa, M.J.; Wagner, E.D.; Schoeny, R.; DeMarini, D.M. Occurrence, genotoxicity, and carcinogenicity of regulated and emerging disinfection by-products in drinking water: A review and roadmap for research. Mutat. Res. Rev. Mutat. Res. 2007, 636, 178-242. [CrossRef] 
56. Yang, Y.; Komaki, Y.; Kimura, S.Y.; Hu, H.Y.; Wagner, E.D.; Mariñas, B.J.; Plewa, M.J. Toxic impact of bromide and iodide on drinking water disinfected with chlorine or chloramines. Environ. Sci. Technol. 2014, 48, 12362-12369. [CrossRef] [PubMed]

57. Xu, X.; Mariano, T.M.; Laskin, J.D.; Weisel, C.P. Percutaneous Absorption of Trihalomethanes, Haloacetic Acids, and Haloketones. Toxicol. Appl. Pharmacol. 2002, 184, 19-26. [CrossRef] [PubMed]

58. De Laat, J.; Feng, W.; Freyfer, D.A.; Dossier-Berne, F. Concentration levels of urea in swimming pool water and reactivity of chlorine with urea. Water Res. 2011, 45, 1139-1146. [CrossRef] [PubMed]

59. Long, L.; Bu, Y.; Chen, B.; Sadiq, R. Removal of urea from swimming pool water by UV/VUV: The roles of additives, mechanisms, influencing factors, and reaction products. Water Res. 2019, 161, 89-97. [CrossRef]

60. Donnermair, M.M.; Blatchley, E.R. Disinfection efficacy of organic chloramines. Water Res. 2003, 37, 1557-1570. [CrossRef]

61. Thickett, K.M.; McCoach, J.S.; Gerber, J.M.; Sadhra, S.; Burge, P.S. Occupational asthma caused by chloramines in indoor swimming-pool air. Eur. Respir. J. 2002, 19, 827-832. [CrossRef]

62. Kaydos-Daniels, S.C.; Beach, M.J.; Shwe, T.; Magri, J.; Bixler, D. Health effects associated with indoor swimming pools: A suspected toxic chloramine exposure. Public Health 2008, 122, 195-200. [CrossRef]

63. Garcia-Villanova, R.J.; Oliveira Dantas Leite, M.V.; Hernández Hierro, J.M.; de Castro Alfageme, S.; García Hernández, C. Occurrence of bromate, chlorite and chlorate in drinking waters disinfected with hypochlorite reagents. Tracing their origins. Sci. Total Environ. 2010, 408, 2616-2620. [CrossRef]

64. Rutala, W.A.; Weber, D.J. Guideline for Disinfection and Sterilization in Healthcare Facilities; Centers for Disease Control and Prevention: Atlanta, GA, USA, 2008.

65. U.S. Department of Health and Human Services. Report on Carcinogens, 15th ed.; U.S. Department of Health and Human Services: Washington, DC, USA, 2021.

66. Deborde, M.; von Gunten, U. Reactions of chlorine with inorganic and organic compounds during water treatment-Kinetics and mechanisms: A critical review. Water Res. 2008, 42, 13-51. [CrossRef]

67. Gulaboski, R.; Mirčeski, V.; Kappl, R.; Hoth, M.; Bozem, M. Review-Quantification of Hydrogen Peroxide by Electrochemical Methods and Electron Spin Resonance Spectroscopy. J. Electrochem. Soc. 2019, 166, 82-101. [CrossRef]

68. Livingston, R.S.; Bray, W.C. The catalytic decomposition of hydrogen peroxide in a bromine-bromide solution. II. Rate measurements in dilute solutions and in the absence of sulfate, and their interpretation as a function of the activity product of hydrobromic acid. J. Am. Chem. Soc. 1923, 45, 2048-2058. [CrossRef]

69. Al-Rehaili, A.M. Comparative chemical clarification for silica removal from RO groundwater feed. Desalination 2003, 159, 21-31. [CrossRef]

70. Recepoğlu, Y.K.; Kabay, N.; Yoshizuka, K.; Nishihama, S.; Yılmaz-Ipek, İ.; Arda, M.; Yüksel, M. Effect of Operational Conditions on Separation of Lithium from Geothermal Water by $\lambda-\mathrm{MnO} 2$ Using Ion Exchange-Membrane Filtration Hybrid Process. Solvent Extr. Ion Exch. 2018, 36, 499-512. [CrossRef]

71. Burguera, E.F.; Meijide-Failde, R.; Blanco, F.J. Hydrogen Sulfide and Inflammatory Joint Diseases. Curr. Drug Targets 2016, 18, 1641-1652. [CrossRef]

72. Davinelli, S.; Bassetto, F.; Vitale, M.; Scapagnini, G. Thermal Waters and the Hormetic Effects of Hydrogen Sulfide on Inflammatory Arthritis and Wound Healing; Elsevier Inc.: Amsterdam, The Netherlands, 2018; ISBN 9780128142547. 